\title{
Prevailing knowledge, practices, attitudes about breast feeding among mothers in Bhagalpur
}

Received: 14.03.2016; Revised: 07.05.2016; Accepted: 18.05.2016

See end of the paper for authors' affiliations MAMTA KUMARI

P.G. Department of Home Science, S.M. College, T.M.Bhagalpur University, BHAGALPUR (BIHAR) INDIA.

Email : mamtakumari9780@ gmail.com
ABSTRACT : The Govt. and non-Govt. organizations throughout the world has realized the importance of Breast feeding under the scheme of 'Health Care for All' and particularly through protection and promotion of Breast feeding. To the practice of Breast feeding is an universal process in recent years. There has been a global decline in the number of Breast feeding mothers. The present investigations was an attempt to evaluate the prevalence of Breast feeding practices in relation to their awareness, knowledge, income, source of knowledge and reason behind Breast feeding. The present study was to spot the variations of child rearing and awareness regarding the feeding practices in the Bhagalpur town - Raionale : (1) to evaluate their awareness and knowledge. (2) to assess the knowledge according to age, income and source of knowledge. Methodology: This study was conducted in different wards of Bhagalpur town. It was Hindu dominated but Muslims respondent were also present, in which slum population was also considered. Total number of 500 subjects were selected, but 96 schedule were rejected due to incomplete answers. Therefore only 404 cases were studied by the researcher. Data were analysed statistically according to the need. Tools for the study - Interview schedule was used for the study. Result : 52.94 per cent subjects in between age group of 21 to 25 yrs. belonged to middle income group. 2.04 per cent respondent belonged to the age group of 30 to $40 \mathrm{yrs}$. were higher income group. 81.18 per cent respondent's source of knowledge regarding Breast feeding was from neighbours and relatives. Only 4.47 per cent got the knowledge through medical advisor. 40.50 per cent respondents belonging to higher income group showed the reasons behind Breast feeding were healthy way. 32.7 per cent respondents belonging to lower income group highlighted about the natural and enough secretion of milk was the main reason. Some reason was followed by 29.16 per cent women belonging to middle income group.

KEY WORDS: Income, Breast feeding, Knowledge, Practices

- HOW TO CITE THIS PAPER : Kumari, Mamta and Singh, Vimi (2016). Prevailing knowledge, practices, attitudes about breast feeding among mothers in Bhagalpur. Asian J. Home Sci., 11 (1) : 176-182, DOI: 10.15740/HAS/AJHS/11.1/176-182. 